\title{
PREVENTIVE MEASURES AND ACTIONS OF THE POLICE OF THE CZECH REPUBLIC AGAINST URBAN VIOLENCE
}

The following article addresses the current problem of urban violence. The aim of the article is to outline the different preventive measures and actions of the Police of the Czech Republic taken in order to prevent urban violence. Moreover, various ways of documentation of illegal acts are presented. Having been the officer in charge during operations conducted against urban violence, the author also shares his practical experience.

\section{Introduction}

Regulation of safety measures against the illegal act of spectator violence (generally also known as urban violence) stems from the binding directive of the Police Headquarters No. 10/2009 entitled "Maintenance of internal order and security". The term "urban violence" comprises various forms of public and collective disturbance of public order in urban areas as well as signs of extremism (music production, radical groups' marches, etc.). The aforementioned directive governs the proceeding of the police when taking measures against negative events which may influence safety situation; when using disciplinary units, anti-conflict teams (ACT), spotters, etc.; when ensuring internal order and security; when ensuring organisation of disciplinary units, their armature, equipment as well as other material and technical provisions.

\section{The origin and history of stadium violence}

The history of football and football violence in particular can be probably traced back to the end of the 19th century. This gave rise to a first football association whose role, among others, was to solve riots at stadiums. Due to increasing violent conflicts, the association had to adopt adequate measures (e.g.: between the years 1895-1897 the English Football Association had to close up 21 football playgrounds and warned other 23 clubs of fans' misconduct. The situation, however, did not improve at the beginning of the 20th century; there were even events during which mass incursions of fans flooded the playgrounds. These were most frequently reactions to umpires' ruling and unsatisfactory performance of football players. During the interwar period, these incidents were no longer the centre of attention ${ }^{1}$. Later, the 1950s became a historical milestone in the history of football fan clubs. The football season 1968-1969 brought about the emergence of large fan groups completely devoted to their teams. The groups did no longer count several, but rather thousands of members, who established their own rituals, symbology, hymns and cries. The worst thing about this new phenomenon was that the purpose of the fans' devotion to one football team or another was not primarily to support their favourite teams, but above all to assault the opposing team's fans and other participants on the day of the match. During the football match, these fans could be seen at their favourite spot - mostly right behind the goal or in the corners of grandstands (known as "End"; the Czech equivalent translates as "Mosh pit" into English). The common spectators often witnessed a violent incident also in the grandstands, as the radical fans of the two teams found pleasure in attacking the other team's "mosh pit".

\section{The situation in the Czech Republic}

The first incidents of football hooliganism in the Czech Republic can be traced back to the beginning of the 1980s. At that time, many fan clubs were founded and their members looked for enemies among the members of other fan clubs who would later, in the grandstands during the match, make a perfect target of their attack. Until then, no mass stadium violence could be seen at football matches in the Czech Republic. I remember the times when we used to go to watch a football match and support our favourite team properly. Our main aim was to watch the game, show some support, have a hot dog, maybe a beer. The football match between Sparta Praha and Dukla Banska Bystrica in 1985 was a real breakthrough in football hooliganism also outside of stadiums - the Sparta Praha fans vandalised a train on their way to Slovakia. The VB (a police force of the Czechoslovak Socialist Republic at that time) had to make the first intervention outside of stadium - at a train station. The event was later made into a film which documented football hooliganism in the republic. The film was entitled '"Why?" and it raised many questions regarding the condemnable misconduct of the Sparta Praha fans. Unfortunately, this film also inspired other

\footnotetext{
* Martin Hrinko

Police CR, KRP Moravskoslezskeho kraje, Ostrava, Czech Republic, E-mail: martin.hrinko@seznam.cz

1) The violent incidents were described as „blaster of hot-heads“ who have a low sense of self-control (King, 1997).
} 
radical fans to organise mass tours to host cities to support their team. With respect to increasing violent incidents connected with football, there was a first fatal accident - one of the radical fans (who participated in a violent encounter of the Sparta Praha fans and the Pilsen fans) followed by police officers, knocked down an old lady at the train station in Pilsen. The next serious accident was caused by the Banik Ostrava fans who, when throwing stones at a train carrying the Sigma Olomouc fans, hit a random passenger. As a result of the accident, the woman went blind for life. Many other casualties were reported (their description and list of all of them would surely exceed the content of this work).

In reaction to this trend (the number of riots at stadiums was approximately the same as the number of riots outside of stadiums), the number of police safety measures accepted and the use of police forces and means increased. As a result, there was a lack of police forces and means during regular guard duties in the streets. Thus, the police on behalf of the Minister of the Interior called for change of legislation. The first amendment was probably imposed by Act No. 283/1991 Coll. on the Police of the Czech Republic, later amended by Act No. 273/2008 Coll. on the Police of the Czech Republic (efficient from 1.1.2009). Among others, this new act led to conclusion of an Agreement between the Football Association of the Czech Republic (abbreviated to FACR) and the Police of the Czech Republic. It regulates their cooperation, construction and technical equipment of the first and second league stadiums, ensurance of security standards, cooperation between the teams' organising service and the police, training and scope of activity of the organising service and common media policy. The Agreement also regulates duties of the subjects who participate in organisation of the match and ensure security. The biggest responsibility for security at stadiums lies with the organising service. If they are unable to deal with a certain situation, they may call the Police of the Czech Republic. The police officers are deployed at the proximity of stadium during a match; they ensure security outside the stadium and ensure safe transfer of the fans to the stadium. This newly imposed procedure provoked many discussions between the FACR officials and the Government, Ivan Langer (the Minister of the Interior, at that time) in particular. Especially, the common spectators were not sure whether their safety was guaranteed, as the security was to be ensured by a private security service, lacking the safety means, the training and the rights needed for execution of the duty. In the Czech Republic, the sports agenda lies in the hands of the Ministry of Education, Youth and Sports of the Czech Republic, which is the state central administrative authority for physical education, sport, hiking and sports representation of the State. Spectator violence agenda lies in the hands of the Ministry of the Interior of the Czech Republic, which is the state central administrative authority for domestic affairs, particularly for public order, other domestic affairs and security [1].

\section{The Police and service regulations}

Based on this directive, the Police convene the forces and means needed in order to ensure public order. Such organised convocation is called a safety measure, police measure or police action, depending on the extent of the measure being taken and on the number of forces and means convened.

"Safety measure" is according to the directive the first and the most extensive measure of the three. This type of measure is performed by the Police and other entities (e.g. § 3, Act No. 239/2000 Coll., $§ 240 / 2000$ Coll.) in order to ensure internal order and security. The recent co-operation among the Integrated Rescue System units (IRS) during the football match between two top teams in the league - FC Banik Ostrava and FC Sparta Praha on 2 May 2010 can serve as an example. During the event, all the services of the Police of the Czech Republic were co-operating: the train escort department, the ACT, the disciplinary units, the heavy armoured personnel, the division of disciplinary and traffic service, the division of crisis management, the criminal police and investigation services, the district departments and the departments of transport. Also, the Municipal Police of Ostrava (the department of hippology, the operative intervention unit, the kynology unit, the municipal police stations), even the Fire Emergency Brigade, members of the Rescue Service teams and - last but not least - officers of Polish Policja were involved in the event. The specific football match is named purposedly in this article - the visiting team's fans' behaviour had to be repressed. During the course of the action, historically, the highest number of people were taken into custody. Having passed the screening, the 370 illegally acting fans were subsequently forced to return to Prague under further supervision of the police forces (see Figs. 1,2).

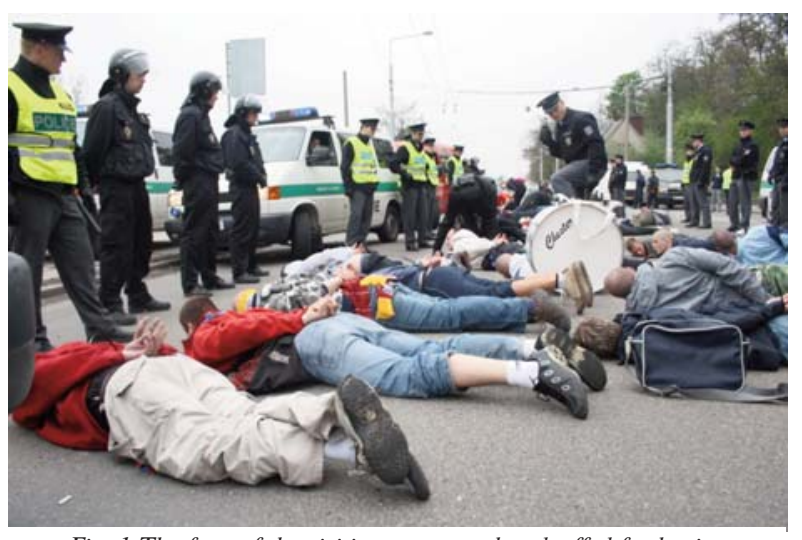

Fig. 1 The fans of the visiting team are handcuffed for having repeatedly refused the orders of the police [1]

Such procedure taken by the Police of the Moravian-Silesian region represented a clear message to football fans - the police are able to supervise and accompany fans securely to the so-called "hazardous matches", so that common traffic and order in cities are not at risk (the police design routes through which, with the assistance from ACT members, the fans are directed). Understandably, the police also ensure security of the fans, so that fights among the fans of the two different teams are prevented. The police are ready to use forces and means needed to suppress any aggressive behaviour of the fans, who, when drunk, often irrationally seek to struggle with the police officers. From my personal experience, 
many fans do not even care how their favourite team are playing or what the actual score is - instead, they tend to focus on how to organize fights with fans of the opposite team, so that they are not suppressed by the police forces.

Safety measure is directed by a Commander, who controls the staff. Both the Commander and the staff are chosen by order of the Chief of Police or the Chief of Regional Headquarters. According to its purpose, safety measure is usually performed by members of IRS units or members of various services of the Police of the Czech Republic available in the location.

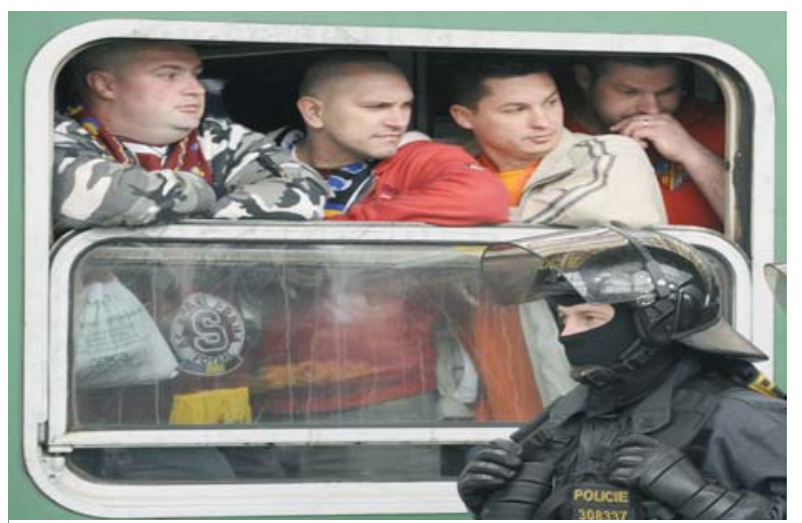

Fig. 2 Fans accompanied by police officers are leaving Ostrava against their will [2]

„Police measures" are in fact very similar to safety measures. However, other IRS units are generally not involved in the course of their action. During a police measure, various police services are combined in order to fulfill the purpose of the measure (e.g. during a foreigner residence check, the following services are involved: the Alien Police, the criminal police and investigation services, police officers from the district offices, etc.) Police measure is directed by a Commander, who is chosen by instruction or order of the Chief of Territorial Division or the Chief of Regional Headquarters.

„Police action“ is a uniphase and temporary operation, during which police measures are performed and which cannot be ensured by common service in a certain area. Proceedings done during an operative elaboration as well as unexpected operations and measures taken to allow the performance of police tasks (e.g. inspections in restaurants, which are performed by forces and means of the relevant district department) are not considered a police action. Police action is directed by a Commander, who is chosen by instruction of the Chief of District Department or the Chief of Territorial Division.

\section{Spotting}

Spotters co-operate with local sports clubs and fans, they monitor hazardous fans and accompany and supervise "their" haz-

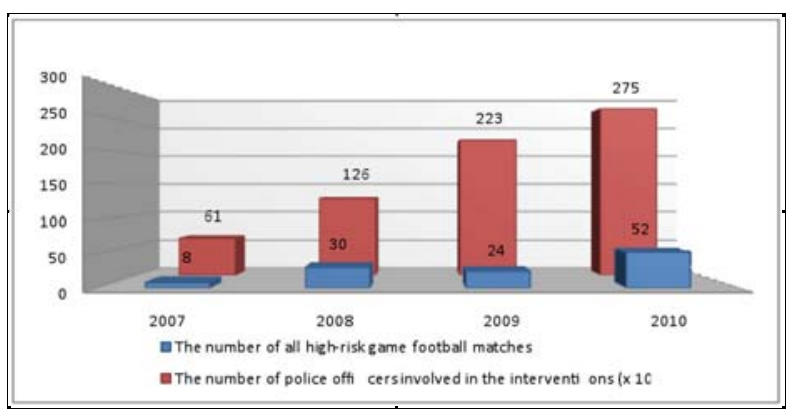

Fig. 3 An overview of all high-risk football matches, during which the order service assisted, and the number of police officers involved in the interventions.

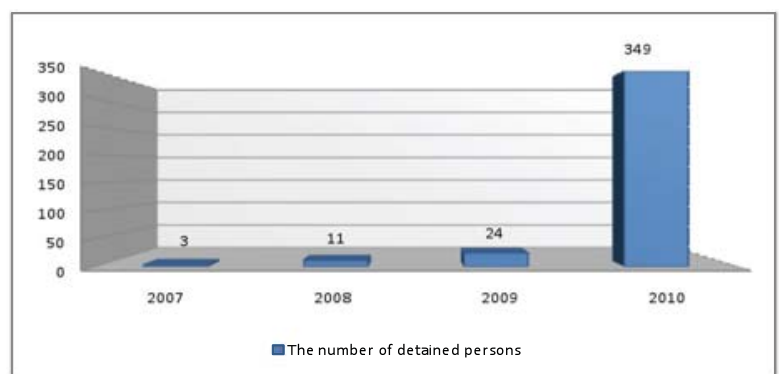

Fig. 4 An overview of the number of persons put under detention during safety interventions at or outside of stadiums in the Moravian-Silesian Region.

ardous fans to and from sports matches. Spotters, who accompany fans, fall under the command of the Commander of the safety measure within the area where the match is played; during hazardous and international matches, the spotter is always a member of the Commander's staff. Spotters undergo a special training which prepares them for work with crowd, knowledge of the particular environment. They also have personal experience with hazardous fans, their behaviour and the potential risks, which might occur. The hazardous fans know their spotters. Spotters stand for a unique documentary team which monitors illegal acts of the fans by hand cameras. Such recordings then help when searching for specific unlawful acts and they represent a very useful supplement to helicopter monitoring of the events. Spotters' shots are done mostly in crowds, from side stands, platforms, tribunes, etc. When shooting, spotters are dressed in civilian attire and they are usually members of the criminal police and investigation services. The shots taken by spotters very often help to prove offenders guilty. If an offender is proven guilty, the Commander tactically decides whether the offender will be taken into custody during the match, during the directed transit, in a means of transport or eventually the following day at the place of his permanent residence.

\section{Anti-conflict team}

The so-called anti-conflict team (abbreviated to ACT) is a new form of preventive action of the police used to prevent unlawful 
conduct during mass public events where disturbance of public order is likely to occur. The establishment of anti-conflict teams was inspired by the Second division of the emergency order service in Berlin (also for other reasons besides the fact that the Berlin police are one of the best in Europe). The original inspiration by the French Crisis Corps' operation was inconvenient due to different rights the Corps possessed (compared with the Czech police). The establishment of anti-conflict teams was also encouraged by JUDr. Otakar Motejl (former public defender of rights - ombudsman) in his assessment report. He criticised the police for insufficient documentation of unlawful conduct committed during high-risk events. He assessed the specific police intervention in Tachov area as lawful, but inadequate. The establishment of three pilot anticonflict teams in the Czech Republic was based on the command of the Chief of Police No. 54/2006. The Czech Republic is currently the second country in Europe to have these preventive police teams. At first, the teams were part of three regional police headquarters - the regional department of North Bohemia (in Ústí nad Labem), North Moravia (in Ostrava) and West Bohemia (in Pilsen). The choice of these three regions was not random, each of these regions experienced violent conflicts with the public. There were several techno parties in North Bohemia and West Bohemia, there are many radical, mostly football fans in North Moravia. Nowadays, also the rest of the Regional Headquarters of the Police of the Czech Republic are involved in the project. There were made some alterations of certain police procedure standards used during police interventions against large groups of people. The basis of the reform of this police procedure is prevention within the framework of tactical prevention interventions. The anti-conflict teams liaise with the police (the order service) and the participants of public events. Among others, their roles are:

- to anticipate aggressive conduct by the means of clear communication (and instruction);

- the members of the team intensely explain the purpose of the police interventions and, if needed, they discuss with citizens the possible problems which may arise from the situation;

- the members of ACT inform the participants of the event about lawful police measures which will be taken in case unlawful conduct occurs.

The members of ACT focus on their target groups (participants of the event, local inhabitants, spectators and the media). The members of ACT are entitled to inform the media about the most basic facts regarding their operation [3].

\section{Ways of monitoring and documenting acts of urban violence}

Besides helicopter monitoring and spotters' shooting of illegal acts, the police also use hand cameras to document both unlawful acts of offenders and action of disciplinary units of the Police of the Czech Republic. These records are shot by police officers of the documentary team of the disciplinary units. Moreover, the police can also use the recordings shot by municipal police stationary cameras or by the Mobile Monitoring Centre (MMC - Commander's truck equipped with cameras and thermovision).

\section{Specific cases of mass behaviour}

Situations where there exists danger of occurrence of mass behaviour (which requires more attention from the order service) can be divided into five categories. In the Czech Republic, judging from the number of the police interventions, the first come spectator violence interventions. Escalation of violence and disturbance of public order often occur during demonstrations. Last but not least, the order service intervenes during mass cultural events, searches and short time safety interventions aimed at vehicle checks (road traffic safety measures) or ensurance of public order (e.g. minors alcohol tests). Essentially, we can distinguish two types of public order surveillance - a coercive style and a consensual style. A coercive style can be characterised by visible presence of the order service and their early employment (paramilitary style). By contrast, a consensual style can be characterised by negotiations, non-violent intervention and communication, which precede the actual employment of the order service. Mass behaviour occurs most likely when the police use command and control' policy. By showing zero tolerance or escalating the forces, the police in fact paradoxically support the groups of people, who are very familiar with acting in the same way. This police style therefore increases influence of the violent groups of people. If the police use negotiation, violent incidents decrease, because the people who encourage and initiate violence do not get much support from other members of the group (unlike when the paramilitary attitude is used). Undoubtedly, the most renowned scientist who studied mass behaviour was Gustave Le Bon. According to his work, a crowd behaves irrationally. The crowd's characteristics are anonymity, mind infection, suggestibility. When being a part of a crowd one's control over their instincts, which they would normally suppress, decreases; their sense of responsibility is low. When being a part of a crowd one essentially becomes a robot, incapable of voluntary behaviour; one becomes a wild uncontrollable creature. The characteristics of a crowd are impulsiveness, changeability, provocativeness, incapability to think reasonably, lack of judgment and critical thinking, emotional exaggeration [4].

\section{Summary}

The phenomenon of spectator violence is certainly not a new one; it is known to have existed for a long time. Unfortunately, it needs to be said that this "English disease" which accompanies football also occurs in the Czech Republic. Consequently, during the high-risk football events, there is ever-present threat of incidents and need for appropriate safety interventions over the course of the fans' journey to and from the particular city, on the routes to and from the stadium, upon their entrance at the stadium and in the grandstands. Many media reports from football matches do not cover only the game itself, but also the football hooliganism caused before, during and after the match. Therefore, we can often see a report from a long-expected football match depicting police cordons and crowds of rioting fans, we can hear police car sirens wailing and it all seems to us as a vulgar and violent show in live broadcast. 
The article described the problem to a phenomenon known as urban violence, which the Police of the Czech Republic gradually and increasingly effective fighting and looking for ways to combat this illegal activity. The interventions of the order service are very demanding and have a very complicated background which cannot be easily revealed to the public. This article attempts to offer at least a partial insight into the background.
In this article the author provides the reader with background work in police practice by starting the article writing from his own practical experience gained in commanding policemen and the establishment of labor and resources of many police actions.

\section{References}

[1] HRINKO, M.: Legal aspects of spectator violence in practice (in Czech), Monographs, Prague 2011: p. 67, Institute of Legal Studies, Prague

[2] Web page link [date accessed: 2.5.2010]: Sparta football fans in Ostrava seen, lying on the road to the stadium (in Czech), Novinky.cz, can be accessed online at: http://www.novinky.cz/domaci/199121-priznivci-sparty-fotbal-v-ostrave-nevideli-lezeli-na-silnici-predstadionem.html.

[3] Web page link [date accessed: 9.1.2011], ZAMEK, D.: Quo Vadis AKT, can be accessed online at: http://bezpecnostnisbory.wbs.cz/clanky/1-2009/Quo_vadis_AKT-1.htm.

[4] JUngWIRTOVA, J.: The Police units and the Mob (in Czech), Prague 2011: The Press Department of the Interior, magazine Policista, No. 1, supplement - pp. VII-X, ISSN 1211-7943. 